\title{
Die erediens as fees of die fees as erediens?: 'n Andrew Murray pryswenner 'n kwarteeu later herlees
}

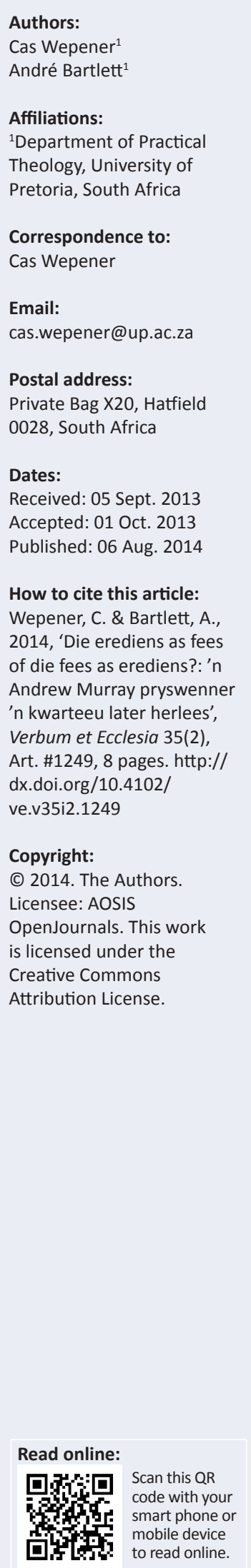

Worship as feast or feast as worship? Re-reading an Andrew Murray prizewinner one quarter of a century later. The aim of this contribution is to bring the book Die erediens as fees into discussion with the surrounding culture almost one quarter of a century after its publication. The surrounding culture, we shall call, following Martin Stringer and his socalled discourse of globalisation and consumerism, 'the feast as worship service'. Based on this discussion, our research question pertains to the value of Die erediens as fees for the field of Liturgical Studies today. An answer is attempted by, firstly, sketching the liturgical landscape as well as national and international liturgical-scientific developments in our day and, secondly, providing a liturgical-aesthetical exploration and positioning Die erediens as fees within these developments and exploration.

\section{Inleiding}

Toe Moses van die berg afkom, was daar volgens Eksodus 32 groot opgewondenheid in die kamp. Dit het so jolig gegaan dat dit geklink het of daar oorlog is! Voorwaar 'n feesviering by uitstek. Vir die skrywers van hierdie bydrae klink sekere liturgiese vieringe in ons eie dag ook soos oorlog in die kamp en wil dit voorkom asof 'fees' en 'viering' die mees basiese en belangrikste kriterium vir die erediens geword het. Natuurlik hang dit af hoe jy fees definieer, maar hier werk ons eers met die populêre gebruik van die woord as opwindend, jolig, genotvol, vermaaklik en uitbundige viering. Ons is van mening dat hierdie verstaan van die konsep 'fees' in ons eie dag so dominant geword het dat ons saam met Martin Stringer (2005) stem dat hier al sprake is van 'n dominante diskoers van globalisering en verbruikerisme. ${ }^{2}$ Die versugting na fees het ook die wyse waarop die erediens ingerig word en insgelyks die smaak van baie erediensgangers in ons eie dag fundamenteel beïnvloed. Tereg haal Müller (1990:1) ook as heel eerste woorde in Die erediens as fees vir Jakobovits aan: 'The pleasure of worship as changed for worship of pleasure.' Is dit net sleg? Moet ons eerder streef na die teenpool, te wete 'n uiters sobere viering gestroop van enige poging om die mens in sy of haar volle liggaamlikheid te betrek? Moet die Apolliniese volledig in die liturgie oor die Dionysiese triomfeer? Natuurlik nie. Dit is dan ook in kort die oogmerk van hierdie bydrae, te wete om die boek Die erediens as fees bykans ' $n$ kwarteeu later in gesprek te bring met 'n omringende kultuur wat ons in navolging van Stringer maar in Afrikaans as 'die fees as erediens' wil tipeer. En op grond van hierdie gesprek wil ons kyk wat die waarde van hierdie boek nog in ons eie dag vir die veld van die Liturgiewetenskap is, al is ons daarvan bewus dat dit in en vir die kerk van meer as twee dekades gelede geskryf is. Ons sal dit eerstens doen deur die liturgiese landskap en Suid-Afrikaanse en internasionale liturgiewetenskaplike ontwikkeling te verken en tweedens deur 'n liturgies-estetiese verkenning te doen. Die artikel sluit met enkele gevolgtrekkings. Met die oog op hierdie verkenning begin ons kortliks met iets meer oor die vakgebied binne die Gereformeerde tradisie.

\section{Die Liturgiewetenskap in Suid-Afrika}

Die Liturgiek of Liturgiewetenskap is in Suid-Afrika 'n besonder klein dissipline met weinig teoloë wat al oor die jare op hierdie bepaalde teologiese akker geploeg het. Hierdie toestand is heeltemal verstaanbaar gegewe die sterk Protestantse tradisie wat vir lank aan teologiese fakulteite aan Suid-Afrikaanse universiteite gehandhaaf is, en dan ook met ' $n$ bepaalde Gereformeerde teologiese aksent. Die gevolg was dat die Bybelwetenskappe en die Sistematiese Teologie tot 'n sterker tradisie ontwikkel het, terwyl die Homiletiek in die Praktiese Teologie as die kroon

1.Wepener: Ek het die voorreg gehad om Julian vir 2 jaar as direkte kollega aan die Universiteit van Pretoria in die Departement Praktiese Teologie te kon hê en ook op 'n persoonlike vlak te leer ken. Ek maak hierdie bydrae met groot waardering vir ' $n$ besondere kollega en vriend.

Bartlett: Ek het Julian in 1978 as studentepredikant leer ken. My waardering vir sy prediking en liturgiese vermoëns het later uitgegroei tot ' $n$ vriendskap wat my lewe en bediening verryk het. Ons dra hierdie artikel aan hom op met groot waardering vir sy kollegialiteit en vriendskap.

2.Stringer maak van Foucault se verstaan van die begrip 'diskoers' gebruik (vgl. Stringer 2005:1012). Ander diskoerse wat hy in sekere historiese periodes van die liturgiegeskiedenis karteer, sluit onder andere ' $n$ hegemoniese, kosmologiese, demotiese en humantistiese diskoers in. Die diskoers van globalisering en verbruikerisme is sy benaming van die periode 1800-2000. 
van die subdissiplines beskou is. Tot 'n groot mate kan gesê word dat die bekende Reformatoriese spreuk Praedicatio verbi Dei est verbum Dei hoofsaaklik en byna uitsluitlik in terme van die gepredikte en dus verbaal gespreekte woord verstaan is, terwyl die sien, voel, proe en selfs ruik van die woord wat ook die woord van God is (vgl. Wepener 2006:387) grootliks verwaarloos is. Soos reeds genoem, was hierdie situasie heeltemal te verstane gegewe die bepaalde tradisie. Ons gaan hierdie bydrae veral op die liturgie van hoofstroom Protestantse kerke in Suid-Afrika en dan by name die Nederduitse Gereformeerde (NG) Kerk afstem. Iemand wat enigsins vertroud is met die verskeidenheid liturgiese uitdrukkingsvorme wat tans (2014) in die NG Kerk aanwesig is, by name iemand soos prof. Julian Müller wat oor die afgelope meer as twee dekades besonder baie proeferedienste in verskeie gemeentes moes evalueer en ook self in verskillende gemeentes voorgaan, weet uit eie waarneming en ervaring dat hierdie sterk verbale, uitsluitlik ouditiewe, woord-gerigte liturgieë in die meeste gemeentes vandag slegs maar 'n hoofstuk in die Suid-Afrikaanse liturgiegeskiedenis verteenwoordig (vgl. ook Wepener 2010a). Onder die invloed van verskeie kragte het die wyse waarop die liturgie gevier word drasties verander. Hoe moet daar oor die huidige stand van sake geoordeel word? Is dit 'n bron van kommer of dalk eerder positiewe ontwikkeling? Of dalk beide?

Dit sal haas onmoontlik wees om binne die bestek van een artikel soos hierdie ' $n$ volledige evaluasie in hierdie verband te doen, maar gegewe die spesifieke fokus van hierdie bundel wil ons tog op 'n bepaalde en voorlopige wyse 'n eerste poging daartoe waag. In hierdie bydrae wil ons soos reeds kortliks genoem die boek Die erediens as fees met die huidige liturgiese landskap in die NG Kerk in gesprek bring. ${ }^{3}$ Dít dan ook op so 'n wyse dat die huidige liturgiese konteks in die NG Kerk aan die hand van hierdie teks geëvalueer word en dat ook die teks aan die hand van hierdie totaal veranderde liturgiese landskap geëvalueer word. Ten einde dit te kan doen, is enkele stappe nodig. Eerstens sal die teks Die erediens as fees binne die ontwikkeling van die Liturgiewetenskap as 'n dissipline in Suid-Afrika en spesifiek aan die hand van die belangrikste boeke wat oor die afgelope dekades op hierdie terrein gepubliseer is, geposisioneer word. Vervolgens sal die liturgiese landskap van die NG Kerk diachronies verken word met besondere klem op die laaste 50 jaar, spesifiek sedert die promulgering van Sacrosanctum Concilium in $1963 .{ }^{4}$ In hierdie verband sal literatuur oor hierdie ontwikkelinge in Europa aan die hand van die werk van Nederlandse liturgiste soos Barnard, Oskamp, Post en Schuman ook bespreek word ten einde die Suid-Afrikaanse ontwikkeling ook beter te situeer. In die lig van hierdie kontekstuele en historiese plasings sal sowel die huidige liturgiese landskap in die lig van die boek verken word as andersom. Laastens sal 'n liturgies-estetiese

3.Ons kies hier doelbewus vir die adjektief 'liturgiese' en nie 'ritueel-liturgiese' nie (vgl. Post 2003) om dit sodoende in te perk tot ' $n$ meer binne-kerklik gerigte verkenning en dus tot liturgiese vieringe wat op die een of ander wyse in verband met die NG Kerk en haar gemeentes staan.

4.Die kongres van die internasionale Societas Liturgica wat in Augustus 2013 in Würzburg, Duitsland, vergader het, het juis ook die tema 'liturgiese hervorming' aangesny in die lig van die feit dat 2013 'die halfeeufeesviering' was van Sacrosanctum Concilium, oftewel 'Die konstitusie oor die heilige liturgie' soos die Sacrosanctum Concilium,
geskrif ook bekend staan. beoordeling ook gedoen word, veral aan die hand van die werk van Gordon Lathrop vanweë sy klem op die ordo wat vir hierdie artikel van besondere waarde is. Die artikel sluit met enkele gevolgtrekkings.

\section{Die Liturgiewetenskap aan die Universiteit van Pretoria aan die hand van akademiese publikasies}

Sonder om enigsins die besondere bydraes uit ander oorde in Suid-Afrika te ontken, kan daar nietemin tereg gesê word dat die Universiteit van Pretoria ' $n$ besonder ryk tradisie in die Liturgiewetenskap het. Name wat hierdie instelling werksaam was, sluit in Pellisier, Du Toit, Barnard, Pieterse, Vos en Müller (vgl. Büchner \& Müller 2009; Burger 2003; Wepener 2013). Belangrike boeke wat hier genoem kan word, sluit in Attie Barnard se Die erediens (1981), Cas Vos and Hennie Pieterse se Hoe lieflik is U woning (1997) en dan natuurlik ook die boek waarop hierdie bydrae fokus en waarmee Julian Müller ook in 1992 die Andrew Murray-prys gewen het, te wete Die erediens as fees (1990). Daar is natuurlik ook nog ander meer gefokusde liturgiewetenskaplike publikasies soos Attie Barnard (1954, 1960) se boeke waarin hy die ontstaan en ontwikkeling van die Pinksterviering in die NG-familie in Suid-Afrika liturgiehistories nagevors het (vgl. Wepener 2008a) of Cas Vos en Dirk Human se publikasies (Human \& Vos 2005) oor liturgie en Psalms.

Binne hierdie korpus liturgiewetenskaplike boeke skryf Müller in die inleiding van Die erediens as fees as volg oor die aanleiding en redes vir die skryf van die boek dat die erediens nie ' $n$ stuk vormgodsdiens moet wees nie, maar dat die erediens met blydskap en genot gedoen moet word met hoë ideale vir die erediens op pad na die hemelse erediens. Terselfdertyd is die erediens egter ook'n empiriese verskynsel en kyk hy ook met 'n funksionele oog na die verskynsel. Sy benadering is egter nie uitsluitlik pragmaties en gefokus op die vraag of iets gaan werk al dan nie (vgl. Müller 1990:1). Müller (1990:1-2) se wens in sy verantwoording is dat meer hulle eerstens sal interesseer in die saak van die erediens en dat meer nog entoesiasties daaraan sal deelneem. 'n Artikel wat op die toekenning van die Andrew Murray-prys gevolg het, vermeld verder dat die boek in die kategorie algemeen godsdienstige publikasies gewen het en gelees behoort te word deur elkeen wat op'n Sondag kerk toe gaan. Die erediens as fees het verder die prys voor 'n totaal van 26 inskrywings weggeraap en die artikel prys die boek onder andere met die volgende woorde aan (Die Kerkbode 1992):

Hierdie boek bied op 'n boeiende wyse raad om die erediens opnuut ' $n$ jubelfees te maak. Meer as net die vanselfsprekende teikengroep van predikante en kerkraadslede word bereik. Die boek is toeganklik vir elke lidmaat. (geen bladsy beskikbaar)

Met hierdie agtergrond in gedagte sal daar vervolgens veral gefokus word op die orde wat inherent is tot die publikasie en dit sal in gesprek gebring word met Suid-Afrikaanse en internasionale ontwikkelings asook 'n liturgies-estetiese blik op die saak. 


\section{Die fees as erediens - oftewel 'n verkenning van die plaaslike en globale liturgiese landskap 'n Beskrywende diachroniese verkenning van
die liturgiese landskap van die NG Kerk}

Die invloed van die Liturgiese Beweging het rondom die 1950's in Suid-Afrika gearriveer, via teoloë soos Pellissier, Du Toit, Barnard en B.A. Müller. Hulle het probeer om vanuit 'n teologiese en historiese herbronning die Gereformeerde liturgie weer met die Gereformeerde tradisie in lyn te bring. Hulle werk word duidelik weerspieël in die amptelike eredienshandleidings van die NG Kerk in hierdie periode soos Die Kerkboek (Algemene Sinode van die NG Kerk 1976). In die jare wat volg, het teoloë soos Müller ook die hand aan die ploeg geslaan en die Handboek vir die erediens (Algemene Sinodale Komitee van die NG Kerk 1988) is 'n produk daarvan. Die Handboek vir die erediens is geskoei op wat ons sal noem die klassiek Gereformeerde diensorde (vgl. Oskamp 1998:11-14) en Die erediens as fees weerspieël ook hierdie ordo. In 'n sekere sin en retrospektief beskou sou Die erediens as fees bykans as 'n soort liturgies-teologiese kommentaar of sekondêre liturgiese bron (vgl. Post 2001:59-61) beskou kon word wat die toenmalige amptelike eredienshandleiding gedien het, bykans soos De weg van de liturgie (Oskamp \& Schuman 1998) in 'n soort tandem met die verskyning van die destydse nuwe Nederlandse Dienstboek gefunksioneer het. Intussen het daar vir die NG Kerk in 2007 'n proefbundel getiteld Vir die erediens verskyn wat in 2010 met 'n neutvars nuwe eredienshandleiding getiteld Handleiding vir die erediens vervang is. Indien hierdie heel nuutste handleiding vir die erediens van die NG Kerk soos haar voorgangers as 'n soort locus theologicus én barometer met betrekking tot die huidige stand van sake ten opsigte van die erediens in die NG Kerk beskou kan word, het die liturgiese landskap in die jare tussen 1988 en 2010 grondig verander (vgl. Wepener 2008b).

Deur slegs na die inhoudsopgawe van die 2010 handleiding te kyk, is dit reeds duidelik dat die grondstruktuur of ordo tussen 1988 en 2010 gewysig is. Om beter in kaart te bring presies wat hierdie verandering behels, is dit handig om na publikasies in die Liturgiewetenskap in Nederland te kyk wat in hierdie selfde periode verskyn het. Dit is dan ook wat in die volgende afdeling gedoen sal word.

\section{Ontwikkelinge wêreldwyd met spesifieke klem op Nederland}

Die sogenaamde Liturgiese Beweging kan beskou word as 'n beweging wat oor rofweg die laaste twee eeue strek waarbinne die vroegste bronne en die liturgiegeskiedenis in 'n sekere sin opnuut ontdek is en wat liturgiese bewuswording en vernuwing gestimuleer het. Daar is teruggegaan na die bronne van die vroeë kerke en liturgiste het gemeen dat ' $n$ sentrale orde waarneembaar is, te wete 'n sogenaamde vierslag wat in essensie bestaan uit 'n Woorddiens en tafeldiens met die voorafgaande versameling en die uitsending aan die einde (vgl. Van der Merwe 2009:165-180), dus vier bewegings. Daar word dikwels na hierdie vierslag-orde as die ekumenies-protestantse orde verwys (vgl. Oskamp 1998:14-18) en dit het wêreldwyd groot inslag geniet. Hierdie en vele ander 'ontdekkings' het grootskaalse liturgiese hervorming en vernuwing gestimuleer wat wêreldwyd in eredienshandleidings van die meeste hoofstroomkerke neerslag gevind het, ook in Nederland. Kort nadat die eredienshandleidings in Nederland hersien en herskryf is en baie van mening was dat die Liturgiese Beweging nou volledig sy beslag gekry het, kondig liturgiste soos Barnard en Post aan dat hulle nou verby die Liturgiese Beweging is en dat daar eerder van Liturgiese Bewegings in die meervoud gepraat moet word (vgl. Barnard 2006; Barnard \& Post 2008; Post 2006a, 2006b, 2010). Volgens hulle het die Nederlandse rituele landskap duidelik aangetoon dat, in daardie konteks waar die dominante uitdrukking een van vloei geword het, hulle verby die Liturgiese Beweging is. Ten slotte kan verwys word na twee resente Nederlandse publikasie, naamlik Immink (2011) se boek Het heilige gebeurt en Barnard (2012) se artikel gebaseer op die boek getiteld Het heilige gebeurt niet.

\section{'n Beskrywende sinchroniese verkenning van die liturgiese landskap van die NG Kerk}

Waar staan ons tans in Suid-Afrika en in die besonder in die NG Kerk met betrekking tot die tema wat hier verken word? Daar bestaan ooreenkomste met die Nederlandse situasie, maar ons is van oortuiging dat die verskille meer is as die ooreenkomste. Daar is oor die algemeen ' $n$ beduidende afname in erediensbywoning in die NG Kerk net soos wat die lidmaattal ook vanweë verskeie redes oor die laaste twee dekades gedaal het. Desnieteenstaande gaan mense steeds in Suid-Afrika en ook in die NG Kerk kerk toe. Die erediens as fees is ' $n$ produk van die Liturgiese Beweging en Nederland is miskien verby die Liturgiese Beweging, maar die NG Kerk is nie. Onses insiens is die ritueel-liturgiese vloei wat in Nederland waarneembaar is ook in SuidAfrika waarneembaar, maar teen 2014 is dit verseker nie die dominante realiteit met betrekking tot die liturgie in die NG Kerk nie. Die heilige gebeur wel nog hier. Hoe sou ons dan die huidige liturgiese landskap in die NG Kerk beskryf? Op grond van persoonlike waarneming en spesifiek ten opsigte van die diensorde som ons dit hier soos volg op (spesifiek beginnende by die soorte wat ons van mening is die meeste voorkom, al het ons nie statistiek om hierdie waarneming te staaf nie):

- 'blended' of konvergensie-liturgie (ook soms genoem 'bricolage')

- klassiek gereformeerde

- charismatiese of pentekostalistiese

- liturgies

- dienste soos adoramus en meditatiewe

- ritueel-liturgiese bewegings buite-om die kerkgebou (vgl. Wepener 2010b). 


\section{Die fees as erediens - 'n liturgies- estetiese verkenning van die liturgiese landskap}

Een manier om binne hierdie landskap van uiteenlopende erediensvorme rigting te vind en veral te verseker dat die erediens nie tot 'n vorm van plesierige vermaaklikheid vervlak nie, is om aan die estetiese aspek van die erediens aandag te gee. Volgens ons kan dit 'n belangrike bydrae lewer om te verseker dat die feestelikheid van die erediens steeds die karakter van 'n erediens sal behou.

Die estetiese vraag word nie uitvoerig of sistematies deur Müller in Die erediens as fees behandel nie. Dit word wel enkele kere direk en meermale indirek aan die orde gestel. Die direkte verwysings na die estetiese kom veral in die bespreking van sang en musiek in die erediens in hoofstuk 6 (Müller 1990:35-44) voor en in 'n mindere mate in hoofstuk 7 waar daar met die erediens en die kerkgebou (Müller 1990:45-51) gehandel word.

Van musiek word daar spesifiek gemeld dat dit'n kunsvorm is en dit word dan ook beskryf as "n kunswerk wat 'n boodskap dra'. Hoewel geen kuns as sodanig kerklik of religieus is nie, meen Müller tog dat dit belangrik is om die vraag te stel watter soort musiek in die erediens pas en watter nie (Müller 1990:39). In antwoord op die vraag gee hy enkele kriteria waaraan die kerklied volgens hom moet voldoen (Müller 1990:42-44). Van die vier kriteria wat hy hanteer, hou slegs die laaste twee streng gesproke met die estetiese vraag verband:

- As kunsvorm bestaan 'n lied (ook die geestelike lied) uit twee komponente: taal en musiek. Omdat hierdie kunsvorm aangewend word om God se lof te besing en 'n draer van die diepste geloofsoortuigings van ' $n$ geloofsgemeenskap te wees, moet dit 'as kunsuiting waardig en van hoogstaande gehalte wees'. Dit vereis, volgens Müller (1) dat 'die woordinhoud aan aanvaarde poëtiese en taalkundige vereistes moet voldoen', (2) dat die 'melodie enersyds van hoogstaande musikale gehalte moet wees, maar andersyds ook die musikale taal van die gelowiges moet kan praat' en (3) dat die woord-toonverhouding van so aard moet wees dat dit 'teks en melodie ... saamvoeg tot 'n hegte eenheid' (Müller 1990:43).

- Met betrekking tot genre is Müller van mening dat, hoewel daar ruimte vir liedere van skuldbelydenis, aanbidding en smeking is, liedere wat geskik is vir die erediens 'gewoonlik in die feestelike kategorie' val. Daarom moet 'n geestelike lied volgens hom van so aard wees dat 'mense dit maklik en van harte kan sing'. Terselfdertyd moet dit 'veral ook op God gerig wees, aangesien Hy die bron van die geloofsgemeenskap se blydskap is' (Müller 1990:43-44).

Oor die kerkgebou wys Müller daarop dat dit 'n materiële uitdrukking is van hoe 'n gemeente sigself en die erediens verstaan, asook hoe 'n gemeente haar betrokkenheid by die wêreld rondom haar verstaan (Müller 1990:40). Aangesien die erediens "n kommunikasieproses (is) wat die totale mens betrek ... beïnvloed sy totale belewenis van die ruimte waar die erediens plaasvind, sy ervaring van elke element van die erediens'. Om daardie rede meen hy 'moet daar ook ruimte wees vir die estetiese en die simboliese' by die beplanning en inrigting van 'n kerkgebou (Müller 1990:47). Wanneer hy egter die basiese beginsels uiteensit waaraan 'n kerkgebou volgens hom moet beantwoord, fokus hy meer op die funksionele as op die spesifiek estetiese (Müller 1990:48). Kuns en simboliek is wel 'gawes wat ... diensbaar kan wees aan die koninkryk van God', maar dit het volgens hom slegs plek in die erediens 'in soverre dit funksioneel aangewend kan word' in belang van die beginsels wat vir 'n kerkgebou geld. 'Sodra dit as noodsaaklik gesien word en die aandag op sigself begin vestig, verbeur dit ' $n$ plek in die gereformeerde erediens' (Müller 1990:49).

Hierdie terughoudendheid by Müller met betrekking tot die estetiese is nie vreemd aan die Gereformeerde benadering tot die erediens nie. Dit is trouens 'n benadering wat oor die algemeen nie met ' $n$ strewe na skoonheid geassosieer word nie, maar eerder met 'n serebrale, gestroopte en selfs anti-estetiese ingesteldheid (Lane 2011:26). In reaksie op die oordrewe gebruik versiering in die Roomse erediens van die laat-Middeleeue het Calvyn en ander Gereformeerde Reformatore groot klem gelê op soberheid ten opsigte van die gebruik van simbole en kunsvorme in die erediens. Dit het met verloop van tyd gelei tot 'n estetiese armoede in die wyse waarop die Gereformeerde erediens ingerig is (Strauss 1995:87; Vos \& Pieterse 1997:114).

Die ironie hiervan is dat daar in die Gereformeerde tradisie 'n baie sterk fokus op die skoonheid van die geskapene as weerspieëling van die heerlikheid van God is (Strydom 1994:16-17). Beginnende by Calvyn word daar in hierdie tradisie gewag gemaak van die skepping as 'teater van die heerlikheid van God', as 'skool vir begeerte' en dus as 'n belangrike middel om mense in verwondering oor en verlange na God te onderrig (Lane 2011:18-19). As deel van die geskape werklikheid word die mens opgeroep om aan die heerlikheid van God uitdrukking te gee, terwyl die lofprysing van die gelowiges tot die herstel van die oorspronklike orde en heelheid van die aarde bydra (Lane 2011:66-67). In dié verband kan daar selfs van die erediens as 'world-sustaining act' gepraat word (Lane 2011:81-82).

Die implikasie hiervan vir 'n estetiese besinning oor die erediens is voor die handliggend. As die skoonheid van die geskape werklikheid die heerlikheid van God weerspieël, moet die skoonheid van die erediens insgelyks tot die verwondering van die mens oor die heerlikheid van God bydra. Nie net die inhoudelike van die erediens nie - dit wil sê die boodskap wat gekommunikeer word - maar ook die vorm waarin dit tot uitdrukking kom, moet met die oorspronklike bedoeling van God met die skepping ooreenstem.

'n Belangrike kwalifikasie wat hier aangebring moet word, is dat skoonheid in Bybelse sin nie dieselfde is as mooiheid of die uitbeelding van slegs die goeie en die deugdelike 
nie. Die skoonheid wat in die erediens gestalte moet vind is ' $\mathrm{n}$ 'vreemde skoonheid' wat die Bybelse narratief van 'creation and redemption, paradise lost and paradise regained, of incarnation, death and resurrection' veronderstel - 'n skoonheid wat waag om te glo 'that in some mysterious way this corrupt world is redeemed by the beauty concealed in the crucified Christ' (De Gruchy 2001:101). Dit gaan oor 'n skoonheid 'chastened by exposure to the gross inhumanities and hypocrisies of our century and others'. Alleen só skoonheid kan volgens De Gruchy as 'a potential source of transformation' beskou word (De Gruchy 2001:99, 101).

Die vraag wat onvermydelik hierdeur opgeroep word, is welke norm aangewend behoort te word om die skoonheid van die erediens te beoordeel. Tussen die uiterstes van estetisme waar dit oor die ervaring van skoonheid as sodanig gaan en waar die erediens hoofsaaklik as kunshandeling beoordeel word en van pragmatisme waar daar gefokus word op 'dit wat werk' en wat aan die behoeftes van erediensgangers beantwoord, moet daar gesoek word na 'n eiesoortige liturgiese estetika wat as maatstaf by die beoordeling van die erediens kan dien (Strydom 1994:1-4).

'n Eerste maatstaf sou wees om te bepaal tot watter soort kuns liturgiese handelinge behoort. Wolterstorff se onderskeiding van drie kategorieë kuns, naamlik verhewe kuns ('high art'), populêre kuns en volkskuns ('works of the tribe') (Wolterstorff 1980:22) is in dié verband bruikbaar. Liturgiese kuns kan dan saam met hom getipeer word as volkskuns (Strydom 1994:37). Dit stem ooreen met Müller se beskrywing van die erediens as 'die fees van die gemeente' en liturgie as 'die hele gemeente se dienswerk wat verrig moet word' (Müller 1990:11-12). Dit lei op sy beurt byna vanselfsprekend tot die vereiste dat liturgiese handelinge deur eenvoud, nugterheid, matigheid en verstaanbaarheid gekenmerk moet word (Strydom 1994:70).

Die belangrikste maatstaf is dat die vorm van die erediens aan die bedoeling of diepste betekenis van die erediens uitdrukking moet gee. In hierdie verband sou daar gebruik gemaak kon word van Müller se bespreking van die hoekstene of kritiese grense van die erediens wat volgens hom ononderhandelbaar is in die vormgewing van die erediens - teenoor die boustene of individuele elemente van die erediens wat van gemeente tot gemeente en van erediens tot erediens kan wissel (Müller 1990:54-56). Die vaste hoekstene wat agtereenvolgens deur Müller in behandeling geneem word is (1) die aanvang en groet, (2) verootmoediging en vryspraak, (3) prediking, (4) sakramente, (5) antwoord en (6) wegsending (Müller 1990:56-105).

Die bruikbaarheid van Müller se hoeksteenmodel word egter beperk deur die feit dat dit uitsluitlik op die tipiese patroon van die Gereformeerd erediens berus, heel spesifiek op die patroon soos wat dit binne die NG Kerk ontwikkel het. Die reikwydte daarvan is gevolglik nie genoegsaam om die erediens binne ' $n$ meer algemene, ekumeniese verband te beoordeel nie. Daarmee saam gee dit ook nie voldoende uitdrukking aan die grondpatroon wat reeds in eerste eeu van die bestaan van die Christelike kerk ontwikkel het (vgl. Hand 2:42 en Justinus die Martelaar, 1 Apologia 67, aangehaal in Lathrop 1998:45) en wat dwarsdeur die eeue die vormgewing van die erediens in die verskillende kerklike tradisies bepaal het nie.

Om dié rede verkies ons eerder om van Gordon Lathrop se model gebruik te maak waar hy van die basiese ordo onderliggend aan die Christelike erediens uitgaan. Dit impliseer nie 'n vaste liturgiese volgorde nie, maar gee uitdrukking aan 'n reeks jukstaposisies wat die patroon van die liturgie bepaal (Bradshaw 2013:4). Die veronderstelling waarop hierdie ordo-model berus, word soos volg verwoord (Lathrop 1998):

Meaning occurs trough structure, by one thing set next to another. The scheduling of the ordo, the setting of one liturgical thing next to another in the shape of the liturgy, evokes and replicates the deep structure of biblical language, the use of the old to say the new by means of juxtaposition. (p. 33)

Die jukstaposisies wat deur Lathrop onderskei word, is die volgende:

- Die ordo van 7 dae en die 8ste dag: Die Christelike kerk het van die begin af die Joodse week van 7 dae met die 7 de dag as sabbat gehandhaaf, maar daarteenoor die viering van die opstanding van Christus op die 1ste dag van die week gestel. Heel vroeg het die gebruik ontstaan om die weeklikse samekoms van die gemeente op die Sondag, dit wil sê die dag ná die sabbat, te hou - 'n patroon wat tot vandag toe die algemene gebruik onder Christene is. Die bedoeling was klaarblyklik (ten minste aanvanklik) nie om die Sondag as die nuwe sabbat te vier nie, maar eerder om die samekoms van die gemeente in jukstaposisie met die bestaande week te plaas - op die 8ste dag (vgl. Joh 20:26) wat tegelyk steeds die 1ste dag van die week was. Deur hierdie jukstaposisie is die opstanding van Christus as die groot beslissende gebeurtenis in die lewe van die geloofsgemeenskap op die voorgrond gestel (Lathrop 1998:36-43).

- Die orde van woord en tafel: Van heel vroeg af het die samekoms van die Christelike gemeenskap die patroon aangeneem van ' $n$ woorddiens met = 'n gemeenskaplike maaltyd wat naas dit geplaas is (vgl. Hand 2:42; Saliers 2013:6). Die samekoms rondom Skrif, uitleg en gebed (die woorddiens) vind waarskynlik sy oorsprong in die sinagogediens van die tyd waarin die vroeë kerk tot stand gekom het, terwyl die oorsprong van die maaltyd waarskynlik enersyds teruggevoer kan word tot die maaltye van Jesus en sy volgelinge, maar andersyds ook tot die gebruiklike maaltye van sosiale klubs wat 'n opvallende verskynsel in die Hellenistiese wêreld was (Lathrop 1998:43-53, 2012:40-41, 2013:4-5). So sterk was die maaltyd as deel van die samekoms van die vroeë Christene gevestig dat die kerk in dié era volgens Lathrop (2012:40) as 'meal fellowship' tipeer kan word en hulle samekomste as 'meal meetings'. Die maaltyd self was heel eenvoudig en het bestaan uit die 
brood wat tipies aan die begin van 'n Joodse sabbatsmaal geëet is en die wyn wat gewoonlik by die afsluiting daarvan gedrink is (Lathrop 1998:43). Die feit dat die maaltyd aan die herdenking van die kruisdood van Jesus verbind is, het verseker dat hierdie gebeurtenis (saam met die opstanding) deurlopend die aandag van die geloofsgemeenskap geniet het (Lathrop 1998:50). Reeds van vroeg af was dit die gebruik om die brood en wyn wat oorgebly het deur die diakens na die lidmate wat nie by die samekoms teenwoordig kon wees nie, te stuur en om ook by die maaltyd 'n kollekte vir die armes te hou. Op dié manier was die samekoms nie bloot na binne gefokus nie, maar ook op die nood van die wêreld (Lathrop 1998:45-46).

- Die ordo van lofprysing en smeking: Ook in die klassieke struktuur van gebed in die Christelike samekoms is die jukstaposisie van een ding wat naas 'n ander geplaas word, na te speur. Aan die een kant word God as skepper en gewer van alle goeie gawes geprys en aan die ander kant word God gesmeek om alle dinge in stand te hou. In sowel die gebed tydens die woorddiens as in die groot eucharistie-gebed voor die maaltyd kan die dubbele fokus van danksegging en smeking onderskei word (Lathrop 1998:55). Die belangrikheid van albei hierdie aspekte van gebed word soos volg deur Lathrop (1998) verwoord:

Thanksgiving alone might be misunderstood to be an acceptance of the status quo, as if the truly religious heart would rise above all actual material suffering to perceive some unearthly religious meaning and so to praise God for all conditions and realities, as if there were no need of God's promise or God's future. Lament alone could be a refusal of comfort and of hope, a choice to hold on to bitterness, as if there were no truth to God's past giving grounds for hope. (p. 57)

Voortspruitend uit die basiese jukstaposisie van lofprysing en smeking of klaagroep is daar van die begin af ook aandag gegee aan voorbidding in die gebed ná die skriflesing en prediking tydens die woorddiens, weereens ook met 'n gerigtheid op die nood van die wêreld.

- Die ordo van lering en wassing: Ook die inisiasie van nuwe lede in die gemeenskap neem die patroon aan van die jukstaposisie van een ding naas 'n ander, in die geval onderrig in die geloof en die wassing van die doop. Hoewel daar in die geskiedenis van die kerk groot meningsverskil en spanning tussen verskillende Christelike geloofsgemeenskappe oor die regte volgorde (eers onderrig wat lei tot geloof en wat dan bevestig word deur die doop, of eers die doop en daarna die onderrig in die geloof) ontwikkel het, is die verband tussen die twee sake telkens weer beklemtoon (Lathrop 1998:59-60). Vir Lathrop (1998) is die spesifieke volgorde minder belangrik as die noue samehang van die twee dele van die proses:

What is important ... is that these two things, teaching and bath, be set beside each other, reinterpreting each other and leading to the meal and to the participation in the life of the church. (p. 66)

- Die ordo van die jaar en Pasga: Soos wat die Christelike Sondag in jukstaposisie tot die week staan, staan die
Paasfees in jukstaposisie tot die res van die jaar (Lathrop 1998:68). Die Joodse pasga wat op sigself reeds 'n jukstaposisie van 'n pre-Israelitiese landboufees en 'n viering van die uittog uit Egipte was, is ten minste sedert middel van die 2de eeu deur sekere Christelike gemeenskappe gevier, maar die verskillende betekenisse van die fees (lente as simbool van nuwe lewe vir die ganse skepping en die bevryding van Israel uit Egipte) is nou met die dood en opstanding van Jesus in verband gebring (Lathrop 1998:69, 72-73). Vanuit hierdie sentrale fokus op die kruisgebeure en opstandingsgebeure rondom Paasfees het die res van die ontwikkeling van die kerklike jaar met verloop van tyd voortgespruit: eers die koppeling van Paasfees met die geherinterpreteerde Joodse Pinksterfees, daarna die uitbreiding van die vastyd voor Paasfees tot 'n tydperk van 50 dae met die oog op die finale voorbereiding van kandidate vir doop tydens Paasfees, vervolgens die herdenking van die dood van martelare en ten slotte die vervanging van die voor-Christelike mid-winterfees met die geboortefees van Jesus (Lathrop 1998:76-77). Die resultaat van hierdie ontwikkeling is dat die verloop van die hele jaar met die groot narratief van die Christelike geloofsgemeenskap in jukstaposisie geplaas is en dat daar aan die gebeure rondom die dood en opstanding van Jesus kosmiese betekenis toegeken is.

Soos reeds gemeld, beskou ons hierdie uiteensetting van Lathrop as 'n geskikte model om die bedoeling of betekenis van die Christelike erediens te ontsluit en derhalwe as ' $n$ bruikbare maatstaf om die estetiese gehalte van 'n bepaalde erediens of van bepaalde liturgiese ontwikkelinge te beoordeel. Dit sou beteken dat die skoonheid (of die gebrek aan skoonheid) van 'n erediens of van sekere liturgiese gebruike gemeet kan word aan die mate waartoe dit uitdrukking gee aan die jukstaposisies van die onderliggende ordo wat op sy beurt aan die diepste bedoelinge van die erediens uitdrukking gee.

Dit is uit die aard van die saak nie moontlik om binne die bestek van hierdie artikel op omvattende wyse 'n beoordeling van enige bepaalde eredienstradisie te gee nie - ook nie van dié van die NG Kerk nie. Daarom word daar in aansluiting by bogenoemde jukstaposisies volstaan met enkele voorlopige waarnemings wat ons beoog om deur verdere ondersoek uit te brei:

- Soos in die meeste ander Christelike kerke word die gewone erediens in gemeentes van die NG Kerk op 'n Sondag gehou en word dit ten minste in teorie as ' $n$ weeklikse viering van die opstanding van Christus beskou. Of dit in die praktyk altyd as opstandingsfees gevier word, is egter te betwyfel. In die loop van die geskiedenis van die NG Kerk is dieSondag in baie kringe as 'n Christelike weergawe van die Joodse sabbat beskou en is die meeste van die Ou-Testamentiese sabbatsbepalings ook op wettiese wyse toegepas. Dit het onder andere tot gevolg gehad dat die erediens in talle gemeentes ' $n$ baie ernstige en selfs somber karakter aangeneem het. Hierdie tendens is in baie gevalle verder deur swaarwigtige en 
wetties-moralistiese prediking versterk. In die onlangse verlede het die situasie egter grootliks verander en het die somber atmosfeer van die erediens vir 'n gemakliker en informeler benadering plek gemaak.

- Ten spyte van vele pogings oor die jare heen om nagmaalviering as deel van die normale eredienspatroon te herstel, is die meeste eredienste in die NG Kerk, soos in feitlik alle ander Protestantse kerke, steeds net 'n woorddiens. Hoewel daar heelwat gemeentes is waar die nagmaal meer gereeld gevier word, is daar egter nog baie gemeentes waar die tradisionele patroon van vier nagmaalgeleenthede per jaar steeds die reël is. Hierdie situasie word verder vererger deurdat die nagmaal, wanneer dit wel gevier word, in baie gevalle nog steeds met die lees van 'n lang, leerstellige formulier gepaard gaan waarin die betekenis van die nagmaal verduidelik word. In die laaste aantal jare is daar heelwat gedoen om alternatiewe vir die nagmaalformulier daar te stel, onder andere verwerkte weergawes van die klassieke eucharistie-gebed (vgl. Clasen, Bartlett \& Schoeman 2010:101-107).

- In die klassieke Gereformeerde patroon van die erediens soos dit ook in die NG Kerk nagevolg is, is daar 'n wisselwerking tussen lofprysing, verootmoediging, skuldbelydenis en danksegging wat op 'n eiesoortige manier uitdrukking gee aan die jukstaposisie van lofprysing en smeking in die basiese ordo soos deur Lathrop beskryf. Onder invloed van die sogenaamde 'praise and worship'-erediensbenadering het die klem in die jongste verlede veral in die gemeentesang al meer op lofprysing en aanbidding begin val, ten koste van elemente soos smeking, verootmoediging en skuldbelydenis. Hierdie toedrag van sake gaan hand aan hand met die feitlike verdwyning van die Psalms in beide gesonge en voorgelese vorm uit baie eredienste van die NG Kerk. Dit is juis in die Psalms waar die noue verband tussen lofprysing en smeking uitdrukking vind en waar die Psalms nie meer gelees of gesing word nie, gaan die noodsaaklike samehang van lof en klag ook verlore.

- Die samehang tussen onderrig, doop en toegang tot die nagmaal is deurlopend in die NG Kerk gehandhaaf. Hierdie samehang blyk onder andere uit die feit dat die bediening van die doop soos in die geval van die nagmaal deur die lees van 'n formulier waarin die betekenis van die doop verduidelik word, voorafgegaan word. Die doop word voorts opgevolg deur 'n jarelange proses van kategetiese onderrig wat op die openbare belydenis van geloof uitloop. 'n Kommerwekkende tendens is die toenemende aandrang by baie lidmate op 'n doopbediening buite die erediens in een of ander private familiekring of vriendekring waardeur die betekenis van die doop as inlywing in die geloofsgemeenskap grootliks verlore gaan. ' $n$ Positiewe ontwikkeling hierteenoor is die feit dat daar in baie gemeentes moeite gedoen word om gereelde doopherinneringsgeleenthede in die erediens te skep (vgl. Clasen et al. 2010:49-51).

- Deur die viering van Kersfees, Goeie Vrydag, Paasfees en Pinksterfees het die patroon van die Christelike kerkjaar wel oor jare die struktuur van die eredienspatroon in die NG Kerk bepaal. Dit is egter veral in die jongste tyd dat daar veel meer aandag gegee word aan die sinvolle viering, nie net van die groot feeste nie, maar ook van die verskillende kerklik-liturgiese seisoene wat daarmee saamhang. Dit blyk onder andere uit die toenemende gebruik van simbole en rituele om aan die karakter van die onderskeie feeste en seisoene uitdrukking te gee (vgl. Clasen et al. 2010:265-359).

Hierdie enkele voorlopige opmerkings verwys na sekere positiewe ontwikkelinge, maar ook na sekere kommerwekkende tendense. Ons is van mening dat Julian Müller met Die Erediens as Fees 'n belangrike bydrae gelewer het om die liturgies-estetiese gehalte van die erediens in die NG Kerk te verhoog en dat dit steeds saam met die werk van ander liturgiese teoloë (soos Gordon Lathrop) kan meehelp om die skoonheid van die ontmoetingsgebeure tussen God en sy gemeente te bevorder.

\section{Die erediens as fees en die fees as erediens}

Die heilige gebeur wél nog ten dele in Suid-Afrika en die NG Kerk en as sodanig bly Die erediens as fees ' $n$ goeie bron. Daar is ook verdere ontwikkelinge en Müller het self ook in die laaste jare probeer om hiermee in gesprek te tree en vanuit 'n narratiewe hoek 'n bydrae te lewer (vgl. Bosman \& Müller 2009). Daar is ook ander publikasies wat baie pertinent hierdie veranderde konteks as uitgangspunt neem (vgl. Barnard, Cilliers \& Wepener 2014). Dit is interessant om te gaan kyk na die nuutste eredienshandleiding in 2010 en daar te sien hoe Die erediens as fees, al werk dit met 'n klassiek gereformeerde orde teenoor die Handleiding vir die erediens se meer ekumenies-Protestantse orde, verseker 'n bron was vir die omskrywings van die verskillende elemente. Müller se uiteensetting van sy boustene binne die Gereformeerde hoekstene het dus duidelik ook boustene binne die nuwe eredienshandleiding se hoekstene geword. Onses insiens dui dit op 'n, alhoewel in die tradisie verander, gesonde buigsaamheid sodat die propria van Müller nie net die ordenarium van Die erediens as fees nie maar ook ander ordenaria kan verryk.

\section{Erkenning Mededingende belange}

Die outeurs verklaar dat hulle geen finansiële of persoonlike verbintenis het met enige party wat hulle nadelig kon beïnvloed in die skryf van hierdie artikel nie.

\section{Outeursbydrae}

C.W. (University of Pretoria) het die artikel geinisiëer en albei outeurs het 'n gelyke bydrae gelewer en as mede-outeurs opgetree.

\section{Literatuurverwysings}

Algemene Sinodale Komitee van die NG Kerk, 1988, Handboek vir die erediens van die Nederduitse Gereformeerde Kerk, N.G. Kerk-Uitgewers, Kaapstad.

Algemene Sinode van die NG Kerk, 1976, Die kerkboek van die Nederduitse Gereformeerde Kerk, N.G. Kerk-Uitgewers, Kaapstad. 
Barnard, A.C., 1954, Die pinksterfees in die kerklike jaar, J.H. Kok, Kampen.

Barnard, A.C., 1960, Eeufees van die pinksterbidure, 1961-1961, N.G. Kerk-Uitgewers, Pretoria.

Barnard, A.C., 1981, Die erediens, NGKB Transvaal, Pretoria.

Barnard, M., 2006, Liturgie voorbij de Liturgische Beweging: Over praise and worship, Thomasvieringen, kerkdiensten in migrantenkerken en ritualiteit op het internet, Meinema, Zoetermeer.

Barnard, M., 2012, 'Het heilige gebeurt niet: Een kritische plaatsbepaling van Gerrit Immink: Het heilige gebeurt', Jaarboek voor liturgie-onderzoek 28, 105-130.

Barnard, M., Cilliers, J.H. \& Wepener, C.J., 2014, Flows of worship in a network culture, Peeters Pers, Leuven. (Liturgia Condenda) (forthcoming).

Barnard, M. \& Post, P., 2008, 'Nogmaals: De Liturgische Beweging voorbij. Enkele kritische kanttekeningen bij de historiografie van het zogenoemde tijdvak van de Liturgische Beweging', Jaarboek voor liturgie-onderzoek 24, 7-22.

Bosman, L. \& Müller, J.C., 2009, "n Narratiewe benadering tot die liturgie', Verbum et Ecclesia 30(2), Art. \#179, 6 pages. http://dx.doi.org/10.4102/ve.v30i2.179

Bradshaw, P.F., 2013, 'Liturgical reform and the unity of Christian churches', referaat gelewer tydens die kongres van Societas Liturgica, Würzburg, 07 Augustus.

Büchner, E.P. \& Müller, J.C., 2009, 'The story of the Department of Practical Theology', Verbum et Ecclesia 30(3), Art. \#153, 5 pages. http://dx.doi.org/10.4102/ ve.v30i3.153

Burger, C.W., 2003, 'Reformed liturgy in the South African context', in L. Vischer (ed.), Christian worship in reformed churches past and present, pp. 159-174, William B. Eerdmans Publishing Company, Grand Rapids.

Clasen, F., Bartlett, F.A. \& Schoeman, F. (reds.), 2007, Vir die erediens: 'n Handleiding, Bybel-Media, Wellington.

Clasen, F., Bartlett, F.A. \& Schoeman, F. (reds.), 2010, Handleiding vir die erediens, Bybel-Media, Wellington.

De Gruchy, J.W., 2001, Christianity, art and transformation: Theological aesthetics in the struggle for justice, Cambridge University Press, Cambridge.

Die Kerkbode, 1992, Julian Müller wen vanjaar die Andrew Murrayprys, besigtig op 24 Julie 2013, by http://www.andrewmurrayprize.co.za/index.php/gallery/ wenners-1980-2013/?nggpage $=2$

Human, D.J. \& Vos, C.J.A., 2005, Psalms and liturgy, T \& T Clark, New York.

Immink, G., 2011, Het heilige gebeurt: Praktijk, theologie en traditie van de protestantse kerkdienst, Zoetermeer, Meinema.

Lane, B.C., 2011, Ravished by beauty: The surprising legacy of reformed spirituality, Oxford University Press, Oxford. http://dx.doi.org/10.1093/acprof:o so/9780199755080.001.0001

Lathrop, G., 1998, Holy things: A liturgical theology, Fortress Press, Minneapolis.

Lathrop, G., 2012, The four gospels on Sunday: The New Testament and the reform of Christian worship, Fortress Press, Minneapolis.

Müller, J., 1990, Die erediens as fees, NGKB, Pretoria.

Oskamp, P., 1998, 'Reportages onderweg', in P. Oskamp \& N. Schuman (reds.), De weg van de liturgie: Tradities, achtergronden, praktijk, pp. 11-22, Zoetermeer, Meinema.

Oskamp, P. \& Schuman, N. (reds.), 1998, De weg van de liturgie: Tradities, achtergronden, praktijk, Zoetermeer, Meinema.
Post, P.G.J., 2001, 'Introduction and application: Feast as a key concept in a liturgical studies research design', in P.G.J. Post, G. Rouwhorst, A. Scheer \& L. Van Tongeren (eds.), Christian feast and festival: The dynamics of Western liturgy and culture, pp. 47-77, Peeters, Leuven.

Post, P.G.J., et al., 2003, Disaster ritual. Explorations of an emerging ritual repertoire, Leuven/ Parys/ Dudley, MA, Peeters. (Liturgia Condenda 15).

Post, P.G.J., 2006a, Liturgische bewegingen: Thema's, trends en perspectieven in tien jaar liturgiestudie: Een literatuurverkenning 1995-2005, Zoetermeer, Meinema.

Post, P.G.J., 2006b, 'Liturgical movements and counter-movements, reorientations and revaluations: A thematic outline', Jaarboek voor liturgie-onderzoek (22) 9-13.

Post, P.G.J., 2010, Voorbij het kerkgebouw: De speelruimte van een ander sacraal domein, Uitgeverij Abdij van Berne, Heeswijk.

Saliers, D., 2013, 'Theological foundations of liturgical reform: One shape of meaning with many forms?', referaat gelewer tydens die kongres van Societas Liturgica, Würzburg, 05 Augustus.

Stringer, M.D., 2005, A sociological history of Christian worship, University Press, Cambridge. http://dx.doi.org/10.1017/СBO9780511614675

Strauss, M.U., 1995, 'Eerste treë in die ontwerp van 'n gereformeerde liturgiese simboliek', Acta Theologica 15(2), 86-95.

Strydom, W.M.L., 1994, Besinning rondom die ontwerp van 'n Protestantshimnologiese estetika, Acta Academica Supplementum, Bloemfontein.

Van der Merwe, I.J., 2009, 'Ontdek die bewegings in die erediens', in C.J. Wepener \& I.J. van der Merwe (reds.), Ontdekkings in die erediens, bl. 165-180, Lux Verbi, Wellington.

Vos, C.J.A., 2005, Theopoetry of the Psalms, Continuum, London.

Vos, C.J.A. \& Pieterse, H.J., 1997, Hoe lieflik is u woning, Raad vir Geesteswetenskaplike Navorsing, Pretoria.

Wepener, C.J., 2006, 'The object and aim of multi-disciplinary liturgical research', Scriptura 93, 384-400.

Wepener, C.J., 2008b, 'Liturgy on the edge of tradition', Praktiese Teologie in SuidAfrika 23(2), 313-335.

Wepener, C.J., 2008a, 'Die mite én die rite: Heuristiese oorwegings vir liturgiehistoriese navorsing na aanleiding van resente ontwikkelinge in die liturgiewetenskap', Nederduitse Gereformeerde Teologiese Tydskrif 49(3/4), 386-399.

Wepener, C.J., 2010a, 'Liturgical research in a changing South African socio-cultural (liturgical) landscape: Challenges and opportunities for method and theory', in I. Swart, J. Erasmus \& S. Green (eds.), Religion and social development in post apartheid South Africa: Perspectives for critical engagement, pp. 403-415, SUN Press, Stellenbosch.

Wepener, C.J., 2010b, 'Nuwe tendense buite-om die erediens van die 21ste eeu: 'n Beskrywende liturgie-historiese en hedendaagse verkenning', Vir die Musiekleier 30(37), 3-19.

Wepener, C.J., 2013, 'Praktiese teologie', in D. Human \& J. van der Merwe (reds.) Die Ned Geref Kerk en teologiese opleiding aan UP: 1938-2013. 75 Jaar, bl. 225247, Universiteit van Pretoria, Pretoria.

Wolterstorff, N., 1980, Art in action: Toward a Christian aesthetic, Eerdmans, Grand Rapids. 